\title{
Experiments with the Lichtman forecasting procedure in the sport segment
}

\author{
Bohumír Štědroň
}

Department of Sport Management, Faculty of Physical Education and Sport, Charles University, Prague, Czech Republic

stedron@ftvs.cuni.cz

This paper was completed with the support of Charles University programme Progres Q19: Social Science Aspects of the Study of Human Movement II.

\begin{abstract}
This article deals with predicting the results of sport games in the selected sports segments. The Potúček (2006) quantitative and qualitative predicting methods (Štědroň, 2012, 2014, 2015) offer many procedures and models. The method of Allan Lichtman, which was tested in the USA during the presidential election, was chosen for our experiment. The method was modified for the sports segment. Preliminary results demonstrate that the analysed method can become a basis for forecasting in sports.
\end{abstract}

\section{KEYWORDS}

prediction; result of a sport game; A. Lichtman's 13 keys model

D0I

10.14712/23366052.2019.5

(c) 2019 The Author. This is an open-access article distributed under the terms of the Creative Commons Attribution License (http://creativecommons.org/licenses/by/4.0), which permits unrestricted use, distribution, and reproduction in any medium, provided the original author and source are credited. 


\section{INTRODUCTION}

Professor Allan Lichtman is an American political historian who teaches at the American University in Washington, D. C. He is a co-author of a model (Lichtman, 2008, 2016) called "Thirteen Keys." Based on a system of statements, this procedure has correctly predicted every American presidential election winner since 1984 and succeeded in making the correct predictions several months or years prior to the elections. The election victory of Republican presidential candidate Donald Trump was the most recent prediction that proved correct. Throughout his U.S. career professor Lichtman has been awarded many acknowledgements and honours such as his appointment as distinguished professor of history in 2011.

At present, prognostic methods are analysed in numerous publications by Štědroň (2012, 2014, 2015), Potůček (2006), Šíma, Bartošek (2016), Šíma, Ruda, Omcirk (2015), Šíma, Omcirk, Ruda (2015).

The Lichtman method was modified for the sports segment by means of brainstorming and application of the Occam's razor principle.

\section{OBJECTIVE}

The purpose of this paper is to propose a modified approach that is based on the Lichtman procedure and can be applied to predict results of sport events. The strategic objective of the study is to initiate a discussion on forecasting methods and receive funding for UK FTVS from international projects.

\section{METHODOLOGY}

The methodology applied in this paper is based on the Occam's razor and Brainstorming methodologies (Štědroň, 2015; Fotr \& Švecová, 2016).

William of Occam was born in England in 1280. He became a Franciscan friar and studied at the University of Oxford. Known as a creative philosopher, he is appreciated as the author of studies that were far ahead of the modern theory of the state. The term Occam's razor refers to the methodological and philosophical principle suggesting that arguments, or entities (particulars), are not to be multiplied without necessity in order to explain a certain phenomenon. Pointless entities should be eliminated. Therefore, this method is also known as the law of parsimony or the principle of minimalism. This approach was commonly applied in medieval philosophy and can even be traced back to Aristotle (Šuleř, 2009).

The term Occam's razor is still used but in a broader, more varied sense. According to the original concept all definitions should be devoid of all useless, auxiliary arguments, however, Occam's method is now also used to assess the correctness of models, e.g. as an arbiter between two or more theories. According this interpretation of Occam's razor, the simpler theory is correct. Occam's razor can also be applied to analyse the causes of individual phenomena and measured data. The simpler, or more probable, of two competing models is more acceptable. 
Occam's principle does not say that the simpler explanation is correct, but it says that the probability of correctness is high and the simpler explanation should be preferred unless evidence to the contrary is available.

Brainstorming, on the other hand, is a significantly younger method. Brainstorming was introduced in the 1930s by Alex Osborn who presented the method as "How to Think Up." Later, it became known as Brainstorming and this method remains the most popular way to stimulate creative thinking.

The recommended format consists of three parts:

- preparatory phase,

- creative discussion of experts specializing in various domains to extract innovative ideas and approaches,

- evaluation and implementation of outcomes.

Professor Lichtman's method is based on an analysis encompassing all U.S. presidential elections from 1860. He developed the methodology in collaboration with Vladimir Keilis-Borok (founder of the International Institute of Earthquake Prediction Theory and Mathematical Geophysics). Lichtman described the algorithm (Lichtman, 2008, 2016) in two publications. His heuristic model consists of thirteen statements that can be assigned a true/false value. Each true statement favours the re-election of the incumbent party. When six or more are false, the challenging party wins. For the D. Trump vs. H. Clinton election battle the thirteen statements were phrased as follows:

1. Party mandate: After the most recent mid-term elections, the incumbent party holds more seats in the House of Representatives. (FALSE)

2. Nomination contest: There is no serious contest for the incumbent party nomination. (TRUE)

3. Incumbency: The incumbent party candidate is the sitting president. (FALSE)

4. Third party: There is no significant third-party candidate (other than Democratic or Republican) or independent campaign. (TRUE)

5. Short-term economy: The economy is not in recession during the term. (TRUE)

6. Long-term economy: Real economic growth during the term equals or exceeds mean growth during the previous two terms. (TRUE)

7. Policy change: The incumbent administration effects major changes in national policy. (FALSE)

8. Social unrest: There is no sustained social unrest during the term. (TRUE)

9. Scandal: The incumbent administration is untainted by major scandal. (TRUE)

10. Foreign/military failure: The incumbent administration suffers no major failure in foreign policy or military affairs. (TRUE)

11. Foreign/military success: The incumbent administration achieves a major success in foreign policy or military affairs. (FALSE)

12. Incumbent charisma: The incumbent party candidate is charismatic or a national hero. (According to Lichtman, Hillary Clinton is short of these attributes, FALSE)

13. Challenger charisma: The challenging party candidate is not charismatic or a national hero. (Neither Trump was assigned with these attributes, TRUE)

The true and false values in the brackets refer to the values of the 2016 United States presidential election. Lichtman's method identified five false statements and eight true statements. The result is that Donald Trump was the winner. This means that, again 
in the 2016 United States presidential election, the Lichtman algorithm proved to be effective.

Failure of Lichtman's method can be demonstrated in the prediction of the 2017 presidential election in France. The opinion poll of voters performed on 9 March showed that Marine Le Pen, chairperson of the National Front party and the European Parliament, was a clear favourite who was expected to advance to the second round while Emmanuel Macron, minister of economy who resigned from his position to concentrate on the presidential election, was supposed to be Le Pen's rival.

\section{ELECTION CAMPAIGN 1}

Marine Le Pen unveiled her presidential platform to voters in Lyon. The manifesto included 144 points mainly dealing with migration and tax policy, France's position in the European Union and the country's security. If Le Pen had become the next president, the attitude towards the European Union would have radically changed in France. Le Pen refused the single currency and called for re-establishment of the national borders. Should the neighbouring countries have denied their consent to restore border crossings, she was determined to hold a referendum, or to pursue the withdrawal of France from the European Union - Frexit. Fighting for making the issuance of French passports more restrictive and deportations of immigrants faster, the immigration policy is the core political concept of the National Front political party. Concerned with the terrorist attacks afflicting France in the recent years, Le Pen intended to recruit 15,000 new police officers in order to increase the size of the security forces. Moreover, she wished to reintroduce the death penalty. Le Pen's main goal was to give France liberty and security, and provide the French with the choice of decision-making.

\section{ELECTION CAMPAIGN 2}

Emmanuel Macron is the head of the En marche political movement with its slogan "France on the move." Politically, he is a social liberal. Macron is an advocate of the "open door" policy towards all migrants and refugees. His campaign was founded on the migration policy that is perceived positively and regarded as an economic tool. He went as far as to challenge France to make a public apology for the French involvement in the Algerian War of 1954-1962. Macron expressed his intent to support business and ease the tax burden for entrepreneurs. Additionally, he encouraged all scientists, economists and entrepreneurs living in the USA, who disagree with Trump's policies, to move to France.

\section{THIRTEEN KEYS FOR FRANCE}

Now, Lichtman's Thirteen Keys algorithm can be used in an attempt to predict the next president of France. Marine Le Pen was chosen to represent the incumbent party while Emmanuel Macron represented the challenging party. The following conclusion was reached: 
1. After the most recent elections, the incumbent party holds more seats in the House of Representatives. (TRUE)

2. There is no serious contest for the incumbent party nomination. (FALSE)

3. The incumbent party candidate is the sitting president. (FALSE)

4. There is no significant independent candidate campaign. (TRUE)

5. The economy is not in recession during the campaign. (TRUE)

6. Real economic growth per capita during the term equals or exceeds mean growth during the previous two terms. (TRUE)

7. The incumbent administration effects major changes in national policy. (FALSE)

8. There is no sustained social unrest during the term. (TRUE)

9. The incumbent administration is untainted by major scandal. (FALSE)

10. The incumbent administration suffers no major failure in foreign policy or military affairs. (TRUE)

11. The incumbent administration achieves a major success in foreign policy or military affairs. (FALSE)

12. The incumbent party candidate is charismatic or a national hero. (TRUE)

13. The challenging party candidate is not charismatic or a national hero. (TRUE)

Five false statements could be identified after applying the thirteen keys algorithm. According the Lichtman procedure, the incumbent party candidate - Marine Le Pen - should have been the winner, but that was not the case.

Understandably, a modified version of professor Lichtman's method must be applied for the sports segment. A modified system of statements was established by means of brainstorming and Occam's razor. Additionally, the system of 0 and 1 as in propositional calculus or Boolean algebra will be applied.

\section{APPLICATION IN THE SPORTS SEGMENT}

Applied in the modified version and based on both a brainstorming session and Occam's razor, Lichtman's method was used to predict if Real Madrid would successfully defend the UEFA Champions League title in 2019. The following predicates were formulated:

- There are no significant changes in the club's management.

- Less than three players were replaced in the incumbent champion's previous year winning line-up.

- The incumbent champion is in great shape and proved this in recent games.

- There is no rival in the contest that is capable of defeating the incumbent champion.

- There is no rival in the contest that is in better shape than the incumbent champion.

- There is no rival in the contest that has a better team than the incumbent champion.

- The incumbent rival ranks among the top three in the Continental League.

- The defending club is untainted by major scandal.

- The incumbent champion is charismatic (high attendance).

- The basic line-up did not change in recent games.

- Not more than one player left the team during the current season.

Results obtained for previous cases:

- AC Milan, incumbent champion in 1989/1990 
- The result (true : false) was $10: 1$

- AC Milan defended the UEFA Champions League title

- AC Milan, incumbent champion in 1990/1991

- The result was $5: 6$

- AC Milan did not defend the UEFA Champions League title

- Real Madrid, incumbent champion in 2016/2017

- The result of prediction was $8: 3$

- Real Madrid dominated the UEFA CL

- Real Madrid, incumbent champion in 2017/2018

- The result of prediction was $7: 4$

- Again, Real Madrid defended the UEFA CL title

To apply the heuristic procedure to the current situation, i.e. Real Madrid in 2018/2019, the following list of predicates is determined:

- There are no significant changes in the club's management (0)

- Less than three players were replaced in the incumbent champion's previous year winning line-up (0)

- The incumbent champion is in great shape and proved this in recent games

- There is no rival in the contest that is capable of defeating the incumbent champion (0)

- There is no rival in the contest that is in better shape than the incumbent champion (0)

- There is no rival in the contest that has a better team than the incumbent champion (0)

- The incumbent rival ranks among the top three in the Continental League

- The defending club is untainted by major scandal

- The incumbent champion is charismatic (high attendance)

- The basic line-up did not change in recent games (1)

- Not more than one player left the team during the current season (0)

The results above $(7: 4)$ indicate that Real Madrid will fail in the future game.

For the purposes of predicting the result of an Ice Hockey World Championship game, the following thirteen keys were defined:

1. The defending club won most games in the previous World Championship.

2. More than one third of the defending club's basic line-up remained the same as in the previous World Championship.

3. The economy is not in recession during the season.

4. Real economic growth equals or exceeds growth during the previous two seasons.

5. There is no change in the defending club's management during the current season.

6. There is no social unrest during the season.

7. The defending club is untainted by major scandal.

8. The defending club reached the quarter-finals in the previous World Championship.

9. The rival did not reach the quarter-finals in the previous World Championship.

10. The defending club is charismatic (high attendance of matches).

11. The rival is not charismatic (poor attendance of matches). 
12. The defending club won the previous game of these two teams.

13. The defending club became the world champion in the recent three years.

The statements listed above can be used to predict the result of the match. The first step consists of determining which team of the selected game is the defending team and which team is the rival team. Thirteen statements are generated after determining the teams, or countries, and years. Each statement is marked as $P_{i}$. There are thirteen statements and, therefore, the variable ranges from 1 to 13 .

$$
i \in\{1 ; 2 ; 3 ; \ldots ; 13\}
$$

In the next step, the veracity of the statements is assessed. Two values are used to express the veracity of the statements.

$$
v\left(\mathrm{P}_{i}\right)=\{0 ; 1\}
$$

Any statement can be either true or false. Function $v\left(\mathrm{P}_{i}\right)$ assigns 1 to each true statement. False statements are assigned with 0 . After assessing the veracity of the statements, each is assigned either with 0 or with 1 . These values must be then summed up.

$$
S=\sum_{\mathrm{i}=0}^{13} v\left(\mathrm{P}_{i}\right)
$$

The sum $S$ determines the number of true statements. It can range from 0 (if neither of the thirteen statements is true) to 13 (if all statements are true).

$$
S \in\{0 ; 1 ; 2 ; \ldots ; 13\}
$$

At the end of the whole procedure the value of the sum $S$ makes it possible to predict the result of the selected game. If most of the statements are true, in other words the value of the sum is at least $7(S \geq 7)$, the incumbent team will win. If, on the other hand, most statements appear to be false and the value of the sum $S$ is 6 or lower $(s \leq 6)$, the rival team will be the winner.

\section{TESTING}

The method was tested on several ice hockey games played at the Ice Hockey World Championships in 2016, 2017, and 2018. The first game of Slovakia and the first game of the United States in each of the years were used as the testing sample.

To assess the selected games, data comprising results from previous years, team line-ups, names of coaches, gross domestic product figures, and changes in these figures were collected. Then, the veracity of each statement was assessed. The outcome of the assessment is shown in Table 1 . 
Table 1 Veracity of statements for games played by the US and Slovak teams

\begin{tabular}{ccccccc}
\hline \multicolumn{7}{c}{$v\left(P_{i}\right)$} \\
\cline { 2 - 7 } & $\begin{array}{c}\text { Canada vs. USA } \\
(2016)\end{array}$ & $\begin{array}{c}\text { Slovakia vs. } \\
\text { Hungary (2016) }\end{array}$ & $\begin{array}{c}\text { USA vs. Germany } \\
(2017)\end{array}$ & $\begin{array}{c}\text { Slovakia vs. Italy } \\
(2017)\end{array}$ & $\begin{array}{c}\text { Canada vs. USA } \\
(2018)\end{array}$ & $\begin{array}{c}\text { Czech Rep. vs. } \\
\text { Slovakia (2018) }\end{array}$ \\
\hline 1 & 1 & 0 & 0 & 0 & 1 & 1 \\
2 & 0 & 1 & 0 & 0 & 0 & 1 \\
3 & 1 & 1 & 1 & 1 & 0 & 1 \\
4 & 0 & 1 & 0 & 0 & 0 & 0 \\
5 & 0 & 0 & 1 & 1 & 0 & 1 \\
6 & 1 & 1 & 1 & 1 & 1 & 1 \\
7 & 1 & 1 & 1 & 1 & 1 & 1 \\
8 & 1 & 0 & 1 & 0 & 1 & 1 \\
9 & 0 & 1 & 0 & 1 & 0 & 1 \\
10 & 1 & 1 & 1 & 1 & 1 & 1 \\
11 & 0 & 0 & 0 & 0 & 0 & 0 \\
12 & 0 & 1 & 0 & 1 & 1 & 1 \\
13 & 1 & 0 & 0 & 0 & 1 & 0 \\
\hline
\end{tabular}

The sum of true statements was calculated for each game and it was determined which of the teams would, according to the method, be the winner. The result obtained was compared with the actual result of the game. The table below shows that the method was successful in determining the winners of all games with the only exception being the game between Canada and the United States of America in 2018. These teams belong among the best in the whole history of the Ice Hockey World Championship. The game was very close and remained tied $(4: 4)$ after overtime. This meant that a shootout had to be played - it was very close again $(1: 2)$ and the final score was $4: 5$. Considering these circumstances, this case was accepted.

Table 2 Method testing

\begin{tabular}{lclcl}
\hline Game & $S=\sum_{i=1}^{13} v\left(P_{i}\right)$ & Winner prediction & Actual result & Validity of method \\
\hline Canada vs. USA (2016) & 7 & incumbent & $5: 1$ & valid \\
Slovakia vs. Hungary (2016) & 8 & incumbent & $4: 1$ & valid \\
USA vs. Germany (2017) & 6 & rival & $1: 2$ & valid \\
Slovakia vs. Italy (2017) & 7 & incumbent & $3: 2$ & valid \\
Canada vs. USA (2018) & 7 & incumbent & $4: 5$ & not valid \\
Czech Rep. vs. Slovakia (2018) & 10 & incumbent & $3: 2$ & valid \\
\hline
\end{tabular}




\section{PREDICTION}

The defined and tested predicates were used to predict the result of the match between Slovakia and the United States of America that is scheduled for 10 May 2019 at the 2019 Ice Hockey World Championship in Slovakia. Table 3 shows the statements regarding the game that have to be assessed as true or false. The United States of America were marked as the incumbent team.

Table 3 Statements applicable to the match USA vs. Slovakia at IIHF WC 2019

\begin{tabular}{|r|l|c|}
\hline$i$ & \multicolumn{1}{|c|}{$P_{i}$} & $V\left(P_{i}\right)$ \\
\hline 1 & USA won most games at IIHFWC 2018. & 1 \\
\hline 2 & More than one third of the basic line-up remained the same as at IIHFWC 2018. & 0 \\
\hline 3 & The economy is not in recession during the season. & 1 \\
4 & Real economic growth equals or exceeds growth during the previous two seasons. & 1 \\
\hline 5 & There is no change in the US team management during the current season. & 1 \\
6 & There is no social unrest during the season. & 1 \\
\hline 7 & The US team is untainted by major scandal. & 1 \\
8 & The US team reached the quarter-finals at IIHF WC 2018. & 1 \\
\hline 9 & Slovakia did not reach the quarter-finals at IIHF WC 2018. & 1 \\
\hline 10 & The US team is charismatic (high attendance of matches). & 0 \\
\hline 11 & The Slovak team is not charismatic (poor attendance of matches). & 1 \\
\hline 12 & The US team won the previous game of these two teams. & 0 \\
\hline 13 & The US team became the world champion in the recent three years (2016-2018). \\
\hline
\end{tabular}

The prediction is regarding a game that will be played in May and, therefore, it is impossible to determine whether all the statements are true or false. The values highlighted in light gray are already clear and will not change with the passage of time. These are statements regarding historical results. In total, there are seven of them. Values highlighted in dark gray may potentially change. They comprise statements the validity of which depends on the future development and situation during the coming season. There are six unclear statements.

$$
S=\sum_{\mathrm{i}=0}^{13} v\left(\mathrm{P}_{i}\right)=10
$$

The veracity of statements highlighted in orange was determined based on currently available data, current economic situation, and previous years' practice. If all 13 statements are taken into consideration, the number of true statements is 10 . This implies that the US team should win this game. It is worth noting, however, that it would be desirable to repeat the whole procedure when the date of the game gets closer to verify the veracity of the statements and, by doing that, to verify the prediction of the result. 
Lichtman's method dealing with the American presidential elections was modified for a completely different domain - the Ice Hockey World Championship. The original statements were adjusted to apply to an ice hockey team and to allow prediction of a result of an ice hockey match. Tested on historical data, the method was proved to be applicable and can be used. The prediction regarding the game between Slovakia and the United States of America at the next World Championship is that Slovakia will fail.

\section{CONCLUSION}

The analysis showed that the interpretation of predicates is a heuristic approach that comprises many scenarios. In the prediction of the most recent presidential election made by professor Lichtman, for example, a change in the assessment of only one statement would change the whole prediction (Hillary Clinton would be the winner).

The results obtained show that the modified Lichtman method is applicable to the sports segment even though the difference between the political and sports environments is so significant (Štědroň, 2015) that Lichtman's heuristic approach cannot be applied in the sports environment without major modifications. To make the prediction more feasible, the keys would have to contain a dynamic comparison of the rivals (sinusoidal pattern of a player or team's performance) rather than remain limited to the defending team. To define such keys, many studies investigating the patterns of sport preparation, training, social links within the team, and the performance sinusoidal pattern would be needed, which would exceed the scope of this study. The brainstorming also indicated that, compared to the number of predicates used in the analysed cases, more than five times more predicates would be necessary to model the sport reality more precisely.

While the application of the Lichtman method on the sports segment is in the early stages of development, the main trend will probably be towards computer systems (instead of Business Intelligence) and "SPORT INTELLIGENCE" applications. It is worth mentioning in connection with the development of artificial intelligence, that Alpha GO, a self-learning computer program defeated Lee Se-dol, Korean GO world champion, in 2016. The future "SPORT INTELIGENCE" system will also be a self-learning system capable of adding predicates in its database autonomously.

\section{REFERENCES}

Fotr, J., Švecová, L. (2016). Manažerské rozhodování: postupy, metody a nástroje. Prague: Ekopress.

Lichtman, A. (2016). Predicting the Next President: The Keys to the White House. Rowman \& Littlefield Publishers.

Lichtman, A. (2008). The Keys to the White House: A Surefire Guide to Predicting the Next President. Rowman \& Littlefield Publishers.

Potůček, M. (2006). Manuál prognostických metod. Prague: Slon.

Šíma, J., Bartošek, D. (2016). Závislost velikosti tržních hodnot účastníků Mistrovství Evropy ve fotbale 2016 na dosaženém výsledku. Acta Academica Karviniensia, 18(3), 50-61.

Šíma, J., Omcirk, V., Ruda, T. (2015). Mistrovství světa ve fotbale 2014 v kontextu tržní hodnoty týmů a jejich umístění. Česká kinantropologie, 19(2), 96-108.

Š́ma, J., Ruda, T, Omcirk, V. (2015). Dependency of Market Value of a Team on the Result Achieved at the FIFA World Cup 2014 in Brazil. Studia Sportiva, 9(1), 267-273. 
Šíma, J., Ruda, T., Omcirk, V. (2013). Dependence of the Overall National Team Market Value on its Success at UEFA EURO 2012. Acta Universitatis Carolinae. Kinanthropologica, 49(2), $32-42$.

Štědroň, B., Čáslavová, E., et al. (2015). Manažerské rozhodování v praxi. Prague: C. H. BECK.

Štědroň, B., Kocour, V. (2014). Technologické prognózy a telekomunikace. Prague: Sdělovací technika.

Štědroň, B., Potůček, M., et al. (2012). Prognostické metody jejich aplikace. Prague: C. H. BECK.

Šulě̌, O. (2009). 100 klíčových manažerských technik: komunikování, vedení lidí, rozhodování a organizování. Brno: Computer Press.

\section{INTERNET SOURCES}

FC Viktoria Plzeň. Úsp̌échy [online]. Available at: <http://www.fcviktoria.cz/zobraz.asp?t =historie-uspechy $>$ Belorussia - Czechia/online broadcasting

Isport [online]. [cit. 2017-05-10]. Available at: https://isport.blesk.cz/hokej/ms-v-hokeji -nemecko-a-francie-2017/belorusko-cesko/online-prenos?match $=259342$

2016 Ice-Hockey World Cup. Wikipedie [online]. [cit. 2017-05-10]. Available at: https:// cs.wikipedia.org/wiki/Mistrovstv\%C3\%AD_sv\%C4\%9Bta_v_ledn\%C3\%ADm_hokeji 2016

https://www.chapters.indigo.ca/en-ca/books/contributor/author/allan-j.-lichtman https://techcrunch.com/2017/05/27/googles-alphago-ai-is-retiring 